\title{
A importância do revisor ad-hoc nos progressos da RBME
}

A Revista Brasileira de Medicina do Esporte (RBME) vem obtendo expressivos progressos nos últimos anos, especialmente após a indexação na base Scielo. Até o presente momento, mais de 200 manuscritos foram submetidos para publicação em 2005, estando a programação de todas as edições completa até o final deste ano. Nosso objetivo atual é obter a indexação no Medline e, para tanto, estamos aprimorando ainda mais a qualidade dos processos da nossa revista.

Nesse contexto, o trabalho do revisor ad-hoc é de fundamental importância. O grande número de artigos submetidos para publicação na RBME implica na necessidade de obtenção de pareceres de especialistas na área de forma ágil, os quais contribuem para a elevação da qualidade das publicações. No entanto, temos vivenciado grandes dificuldades, já que muitas vezes os pedidos de parecer não são respondidos ou apresentam respostas inconsistentes. As principais causas deste problema são a mudança de endereço eletrônico do revisor, meio de contato utilizado pela revista para solicitação dos pareceres e a impossibilidade do consultor em emitir seu parecer em tempo hábil. Com o objetivo de solucionar esta questão estamos efetuando o recadastramento de todos os revisores e atualizando as informações, incluindo o que diz respeito à área de emissão de pareceres. Este item é de fundamental importância, pois constitui a nossa base de dados para direcionamento dos manuscritos aos revisores.

Segundo as normas da RBME, temos um prazo de 30 dias para enviar o parecer aos autores. É natural e compreensível que, algumas vezes, a solicitação de parecer venha em um momento atribulado do revisor, impossibilitando-o de emitir este parecer dentro do prazo solicitado. A não resposta do revisor, ou a emissão de pareceres evasivos, carentes de justificativas e detalhamentos, têm-nos custado um atraso significativo nas publicações. A obrigatoriedade de preenchimento de todos os campos no formulário de emissão do parecer tem como objetivo permitir que o revisor possa contribuir com sua experiência no aprimoramento daquele manuscrito, o que representa o principal instrumento de estímulo ao aumento da qualidade dos artigos publicados na RBME. Sendo assim, pareceres que sugiram a recusa do referido manuscrito pelo revisor sem justificativa serão reencaminhados ao mesmo para que forneça argumentos fundamentando tal sugestão.

Gostaríamos de informar que a edição comemorativa dos 10 anos da RBME (novembro/ dezembro de 2005) apresentará uma lista dos revisores que contribuíram com a revista neste ano, servindo como comprovante de sua colaboração. A partir de 2006, os revisores recadastrados que estejam participando efetivamente na revisão dos manuscritos terão seus nomes publicados em todas as edições da RBME, como forma de retribuir e reconhecer regularmente a valiosa contribuição oferecida por eles ao desenvolver este trabaIho.

Ainda como parte da comemoração dos 10 anos da RBME, premiaremos os cinco revisores que tanto têm contribuído conosco ao emitir o maior número de pareceres dentro dos limites de tempo e qualidade acima especificados. O resultado será divulgado no dia 5 de dezembro através de e-mail.

Agradecemos imensamente a todos os revisores que, com sua agilidade, atenção e presteza, vêm colaborando para o crescimento da RBME. As vitórias obtidas têm grande participação de vocês. Vamos rumo à indexação no Medline!

Atenciosamente,

Kelb Bousquet Santos Editora de Área

Renata Rodrigues Teixeira de Castro Editora Associada

Antonio Claudio Lucas da Nóbrega Editor Chefe 